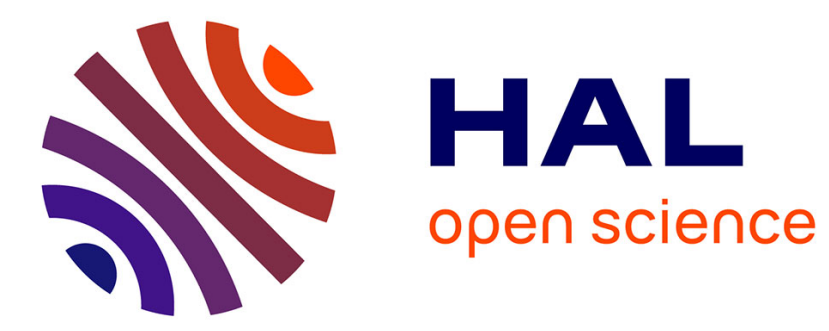

\title{
Structure and properties of the mixed-valence compound Eu5Zr3S12
}

Dirk Johrendt, Petra Jakubcova, Falko M. Schappacher, Rainer Pöttgen

\section{To cite this version:}

Dirk Johrendt, Petra Jakubcova, Falko M. Schappacher, Rainer Pöttgen. Structure and properties of the mixed-valence compound Eu5Zr3S12. Journal of Inorganic and General Chemistry / Zeitschrift für anorganische und allgemeine Chemie, 2009, 635 (4-5), pp.759. 10.1002/zaac.200900075 . hal00482074

\section{HAL Id: hal-00482074 https://hal.science/hal-00482074}

Submitted on 8 May 2010

HAL is a multi-disciplinary open access archive for the deposit and dissemination of scientific research documents, whether they are published or not. The documents may come from teaching and research institutions in France or abroad, or from public or private research centers.
L'archive ouverte pluridisciplinaire HAL, est destinée au dépôt et à la diffusion de documents scientifiques de niveau recherche, publiés ou non, émanant des établissements d'enseignement et de recherche français ou étrangers, des laboratoires publics ou privés. 


\section{Structure and properties of the mixed-valence compound Eu5Zr3S12}

\begin{tabular}{|c|c|}
\hline Journal: & Zeitschrift für Anorganische und Allgemeine Chemie \\
\hline Manuscript ID: & zaac. 200900075 \\
\hline Wiley - Manuscript type: & Article \\
\hline $\begin{array}{r}\text { Date Submitted by the } \\
\text { Author: }\end{array}$ & 30-Jan-2009 \\
\hline Complete List of Authors: & $\begin{array}{l}\text { Johrendt, Dirk; LMU Muenchen, Department Chemie und Biochemie } \\
\text { Jakubcova, Petra; LMU München, Chemie und Biochemie } \\
\text { Schappacher, Falko M.; Universität Münster, Anorganische Chemie } \\
\text { Pöttgen, Rainer; Universität Münster, Anorganische Chemie }\end{array}$ \\
\hline Keywords: & Europium, Mixed valence, Sulfides, Magnetism, Crystal structure \\
\hline
\end{tabular}

\section{S scholaroNE" \\ Manuscript Central}




\title{
Structure and properties of the mixed-valence compound $\mathrm{Eu}_{5} \mathrm{Zr}_{3} \mathrm{~S}_{12}$
}

\author{
Petra Jakubcová $^{\mathrm{a}}$, Falko M. Schappacher ${ }^{\mathrm{b}}$, Rainer Pöttgen ${ }^{\mathrm{b}}$ and Dirk Johrendt ${ }^{\mathrm{a}, *}$
}

Dedicated to Professor Reinhard Nesper on the Occasion of his $60^{\text {th }}$ Birthday

a Department Chemie und Biochemie, Ludwig-Maximilians-Universität München, Butenandtstrasse 5-13 (Haus D), D-81377 München (Germany)

b Institut für Anorganische und Analytische Chemie, Westfälische WilhelmsUniversität Münster, Corrensstraße 30, 48149 Münster (Germany)

\begin{abstract}
Needle shaped crystals of $\mathrm{Eu}_{5} \mathrm{Zr}_{3} \mathrm{~S}_{12}$ and $\mathrm{Eu}_{3.67} \mathrm{Sr}_{1.33} \mathrm{Zr}_{3} \mathrm{~S}_{12}$ were synthesized by solid state reactions of the elements and $\mathrm{ZrS}_{2}$ at $673-1273 \mathrm{~K}$ in alumina crucibles and their crystal structures were determined by single crystal methods. Both are isotypic with hexagonal symmetry (space group $P \overline{6} 2 m, Z=1, \mathrm{Eu}_{5} \mathrm{Zr}_{3} \mathrm{~S}_{12}: a=1170.7(2), c=$ 394.27(8) pm, $w R 2=0.0636$ for $552 F^{2}$ and 27 parameters; $\operatorname{Eu}_{3.67} \mathrm{Sr}_{1.33} \mathrm{Zr}_{3} \mathrm{~S}_{12}: a=$ 1167.0(2), $c=395.71(8) \mathrm{pm}, w R 2=0.0887$ for $484 F^{2}$ and 29 parameters) and contain one-dimensional chains of edge-sharing $\mathrm{ZrS}_{2} \mathrm{~S}_{4 / 2}$ octahedra, running parallel to [001]. Two europium sites are seven- or nine-fold coordinated by sulfur. $\mathrm{Eu}_{5} \mathrm{Zr}_{3} \mathrm{~S}_{12}$ is a Curie paramagnet with an effective magnetic moment of $\mu_{\text {eff }}=13.37(1) \mu_{\mathrm{B}} / \mathrm{fu}$ in agreement with three $\mathrm{Eu}^{2+} / \mathrm{fu} .{ }^{151} \mathrm{Eu}-\mathrm{Mößbauer}$ spectra show two absorption lines suggesting a static mixture of $\mathrm{Eu}^{2+}$ and $\mathrm{Eu}^{3+}$ according to $\mathrm{Eu}_{3}^{2+} \mathrm{Eu}_{2}^{3+} \mathrm{Zr}_{3}^{4+} \mathrm{S}_{12}^{2-}$. This assignment is not in line with the observed $\mathrm{Eu}-\mathrm{S}$ distances. To resolve this, we suggest pure $\mathrm{Eu}^{2+}$ at the $2 c$ site and inhomogeneous mixed valence at the $3 f$ site according to $\left(\mathrm{Eu}_{2}^{2+}\right)^{2 c}\left(\mathrm{Eu}^{2+} \mathrm{Eu}_{2}^{3+}\right)^{3 f} \mathrm{Zr}_{3}^{4+} \mathrm{S}_{12}^{2-}$. This is supported by the site preference of $\mathrm{Sr}^{2+}$ in $\mathrm{Eu}_{3.67} \mathrm{Sr}_{1.33} \mathrm{Zr}_{3} \mathrm{~S}_{12}$.
\end{abstract}

Running title: Mixed valence in $\mathrm{Eu}_{5} \mathrm{Zr}_{3} \mathrm{~S}_{12}$

Keywords: $\quad$ Europium, Sulfides, Crystal structure, Mixed valence, Magnetism 
* Prof. Dr. Dirk Johrendt

Department Chemie und Biochemie, Universität München

Butenandtstrasse 5-13 (Haus D), D-81377 München, Germany

e-mail: dirk.johrendt@cup.uni-muenchen.de

\section{Introduction}

Mixed valence compounds have been a matter of interest for decades [1]. In solids, europium can be divalent $\left(\mathrm{Eu}^{2+}, 4 \mathrm{f}^{7}\right)$ or trivalent $\left(\mathrm{Eu}^{3+}, 4 \mathrm{f}^{6}\right)$ and fluctuations between these configurations frequently occur. In structures with one crystallographic Eu site and fast fluctuation frequencies, $\mathrm{Eu}^{2+}$ and $\mathrm{Eu}^{3+}$ are not observable separately and thus homogeneously-mixed (intermediate) valence results. Di- and trivalent europium ions on different crystallographic sites can lead either to a static valence mixture or inhomogeneous mixed-valence if the fluctuation frequency depends strongly on temperature. In the latter case, the europium ions become equivalent above the Verweytemperature. Homogeneous mixed-valence is known from metallic compounds like $\mathrm{EuCu}_{2} \mathrm{Si}_{2}$ [2] or $\mathrm{EuNi}_{2} \mathrm{P}_{2}$ [3]. The non-metallic compounds $\mathrm{Eu}_{3} \mathrm{O}_{4}$ [4], $\mathrm{Eu}_{2} \mathrm{CuS}_{3}$ [5] and $\mathrm{Eu}_{5} \mathrm{Sn}_{3} \mathrm{~S}_{12}$ [6] are examples for static mixed-valence with different europium sites. Inhomogeneous mixed-valence associated with Verwey-transitions have been observed in $\mathrm{Eu}_{3} \mathrm{~S}_{4}$ [7], $\mathrm{Eu}_{4} \mathrm{As}_{3}$ [8] and in the metallic compounds EuPtP [9, 10], EuPdAs [11] and EuNiP [12, 13].

Recently, we reported on the ternary thiostannate $\mathrm{Eu}_{5} \mathrm{Sn}_{3} \mathrm{~S}_{12}$, a mixed valence compound with three $\mathrm{Eu}^{2+}$ and two $\mathrm{Eu}^{3+}$ occupying five different crystallographic sites [6]. The static nature of the valence mixture was verified by ${ }^{151}$ Eu-Mößbauer spectra, showing two separate absorptions with almost temperature-independent chemical shifts. In $\mathrm{Eu}_{5} \mathrm{Sn}_{3} \mathrm{~S}_{12}$, the assignments of the $\mathrm{Eu}^{2+}$ and $\mathrm{Eu}^{3+}$ sites are in line with the different europium coordinations, hence the divalent ions with larger radii $\left(\mathrm{Eu}^{2+} 117 \mathrm{pm} ; \mathrm{Eu}^{3+} 95\right.$ $\mathrm{pm}$ ) occupy positions with significantly longer $\mathrm{Eu}-\mathrm{S}$ distances and vice versa. This, however, is also consistent with the charge balanced formula $\mathrm{Eu}_{3}^{2+} \mathrm{Eu}_{2}^{3+} \mathrm{Sn}_{3}^{4+} \mathrm{S}_{12}^{2-}$ as expected by the semiconducting behaviour of the material.

We noticed the existence of the europium-thiozirconate with the same formula type. $\mathrm{Eu}_{5} \mathrm{Zr}_{3} \mathrm{~S}_{12}$ [14] crystallizes in a similar, but hexagonal structure with two crystallographic europium sites, namely one threefold and one twofold. This is suggestive of assigning the 
threefold site with $\mathrm{Eu}^{2+}$ and the twofold with $\mathrm{Eu}^{3+}$ resulting in the charge balanced formula $\mathrm{Eu}_{3}^{2+} \mathrm{Eu}_{2}^{3+} \mathrm{Zr}_{3}^{4+} \mathrm{S}_{12}^{2-}$ as indicated by the authors. However, the compound has been obtained only as a by-product of another synthesis in Ref. [14] and no further data beyond the structure are given. In this paper, we report on the synthesis, single crystal structure determination, magnetic properties and ${ }^{151}$ Eu-Mößbauer spectroscopy of the mixedvalence compound $\mathrm{Eu}_{5} \mathrm{Zr}_{3} \mathrm{~S}_{12}$.

\section{Experimental}

Synthesis

$\mathrm{Eu}_{5} \mathrm{Zr}_{3} \mathrm{~S}_{12}$ was synthesized by heating a mixture of Eu metal (99.9\% Smart Elements), $\mathrm{ZrS}_{2}$ and $\mathrm{S}(99.999 \%$, ChemPur) in a $\mathrm{NaCl} / \mathrm{KCl}$ flux in an alumina crucible, which was sealed in a silica tube under an atmosphere of purified argon. The sample was heated to $943 \mathrm{~K}$ at a rate of $50 \mathrm{~K} / \mathrm{h}$, kept at this temperature for $72 \mathrm{~h}$ and slowly cooled down to $673 \mathrm{~K}$ at a rate of $3 \mathrm{~K} / \mathrm{h}$ and then to room temperature at a rate of $50 \mathrm{~K} / \mathrm{h}$. The crucible was smashed and the $\mathrm{NaCl} / \mathrm{KCl}$ flux dissolved in warm water. This procedure resulted in needle gray crystals of $\mathrm{Eu}_{5} \mathrm{Zr}_{3} \mathrm{~S}_{12}$, which are stable in air.

$\mathrm{Eu}_{3.67} \mathrm{Sr}_{1.33} \mathrm{Zr}_{3} \mathrm{~S}_{12}$ could be obtained by heating a stoichiometric mixture of Eu metal, (99.9\%, Alfa Aesar), S (99.999\%, ChemPur), SrS and $\mathrm{ZrS}_{2}$ at $1275 \mathrm{~K}$ for 130 hours. After cooling, the sample is homogenized and heated to $1275 \mathrm{~K}$ for $69 \mathrm{~h}$. This procedure resulted in a multiphase mixture with needle-shaped gray crystals of $\mathrm{Eu}_{3.67} \mathrm{Sr}_{1.33} \mathrm{Zr}_{3} \mathrm{~S}_{12}$.

\section{$X$-ray structure determination}

X-ray powder patterns of the $\mathrm{Eu}_{5} \mathrm{Zr}_{3} \mathrm{~S}_{12}$ and $\mathrm{Eu}_{3.67} \mathrm{Sr}_{1.33} \mathrm{Zr}_{3} \mathrm{~S}_{12}$ samples were recorded using a StOE STADI-P diffractometer (Mo-K $\mathrm{K}_{\alpha 1}$ radiation, Ge(111)-monochromator, $7^{\circ} \mathrm{PSD}$ detector or $\mathrm{Cu} K \alpha_{1}$ radiation, $\mathrm{Ge}(111)$-monochromator, $\mathrm{SiO}_{2}$ as external standard).

Small single crystals of $\mathrm{Eu}_{5} \mathrm{Zr}_{3} \mathrm{~S}_{12}$ and $\mathrm{Eu}_{3.67} \mathrm{Sr}_{1.33} \mathrm{Zr}_{3} \mathrm{~S}_{12}$ were selected directly from the samples and inspected by Laue photographs (white Mo-radiation). Single crystal intensity data were collected at room temperature on a STOE IPDS imaging plate detector (Mo-Ka, graphite-monochromator, $\varphi$-scan). The EXPOSE [15] and X-RED [16] software was used for data collection and processing. Analytical absorption corrections were performed using crystal shapes obtained by the video system and optimized by the X-SHAPE [17] software. 
The structures were solved with the direct methods program SHELXS and refined with full-matrix least squares using SHELXL [18]. All final cycles included anisotropic displacement parameters.

Crystallographic data and experimental details of the data collections are listed in Table 1, final atomic positions and equivalent displacement parameters in Table 2. Selected interatomic distances are given in Table 3. Further details of the structure determinations may be obtained from: Fachinformationszentrum Karlsruhe, D-76344 EggensteinLeopoldshafen (Germany) by quoting the Registry No's CSD-420279 $\left(\mathrm{Eu}_{5} \mathrm{Zr}_{3} \mathrm{~S}_{12}\right)$ and CSD-420280 ( $\left.\mathrm{Eu}_{3.67} \mathrm{Sr}_{1.33} \mathrm{Zr}_{3} \mathrm{~S}_{12}\right)$.

\section{Electrical resistivity}

A cold pressed pellet (diameter $6 \mathrm{~mm}$, height $\sim 1 \mathrm{~mm}$ ) of the $\mathrm{Eu}_{5} \mathrm{Zr}_{3} \mathrm{~S}_{12}$ powder sample was contacted with silver wires and silver paste and the specific electrical resistivity was measured between 80 and $320 \mathrm{~K}$ using a $d c$ four point current reversal method [19].

\section{Magnetic measurements}

Magnetic properties of $\mathrm{Eu}_{5} \mathrm{Zr}_{3} \mathrm{~S}_{12}$ were measured with a SQUID magnetometer (MPMSXL Quantum Design Inc.). Finely ground powder sample was inserted in capsules and those into a straw of known diamagnetism. The magnetic susceptibilities of the sample were collected in a temperature range from 1.8 to $300 \mathrm{~K}$ with magnetic flux densities up to 5 Tesla. The data were corrected for diamagnetic contributions of the capsule, the straw and the sample using diamagnetic increments [20,21].

${ }^{151}$ Eu-Mössbauer spectroscopy

The $21.53 \mathrm{keV}$ transition of ${ }^{151} \mathrm{Eu}$ with an activity of $130 \mathrm{MBq}(2 \%$ of the total activity of a ${ }^{151} \mathrm{Sm}: \mathrm{EuF}_{3}$ source) is used for the Mössbauer spectroscopic experiments which were conducted in the usual transmission geometry. The measurements were performed with a commercial helium bath cryostat. The temperature of the absorber was varied between 4.2 $\mathrm{K}$ and room temperature, while the source was kept at room temperature. The sample was placed within a thin-walled PVC container at a thickness corresponding to about $10 \mathrm{mg}$ $\mathrm{Eu} / \mathrm{cm}^{2}$. The material for the Mössbauer spectroscopic measurements and the magnetic investigations was taken from the same batch. 


\section{Results and discussion}

The crystal structure of $\mathrm{Eu}_{5} \mathrm{Zr}_{3} \mathrm{~S}_{12}$ (space group $P \overline{6} 2 \mathrm{~m}$ ) is shown in Figure 1. The unit cell consists of one formula unit with two crystallographically different Eu sites, one $\mathrm{Zr}$ and three $\mathrm{S}$ sites. The europium atoms at the Wyckoff positions $2 c$ and $3 f$ are coordinated by sulphur atoms either in the shape of tri-capped (Eu1) or single capped (Eu2) trigonal prisms, as shown in Figure 2. Nine sulphur atoms surround Eu1 at distances of 303.0-340.1 pm. Eu2 is sevenfold coordinated with Eu-S bond lengths of $286.5(2)-291.5(3) \mathrm{pm}$. These prisms share faces or edges and thus form chains. $\mathrm{Zr}$ is found in a sixfold octahedral co-ordination sphere consisting of sulphur atoms with $\mathrm{Zr}-$ $\mathrm{S}$ bond lengths between 254.9(2) and 265.1(2) pm. One-dimensional chains of edgesharing $\mathrm{ZrS}_{2} \mathrm{~S}_{4 / 2}$ octahedra run parallel to [001] (Figure 3).

According to the interatomic distances, the assignment of the europium valences seems to be straightforward. $\mathrm{Eu}^{2+}$ should clearly occupy the $2 c$ site with a mean Eu1-S distance of $315.4 \mathrm{pm}$ and $\mathrm{Eu}^{3+}$ is expected on the $3 f$ site with a mean Eu2-S distance of $288.3 \mathrm{pm}$. This would be completely in line with known europium sulfides, where $\mathrm{Eu}^{2+}-\mathrm{S}$ distances are always significantly longer than $\mathrm{Eu}^{3+}-\mathrm{S}$ distances. Examples are EuS (298 pm), Eu $\mathrm{S}_{3}(270 \mathrm{pm}), \mathrm{EuZrS}_{3}(311 \mathrm{pm})$ as well as the static mixed valence compounds $\mathrm{Eu}_{5} \mathrm{Sn}_{3} \mathrm{~S}_{12}(306 / 286 \mathrm{pm})$ and $\mathrm{Eu}_{2} \mathrm{CuS}_{3}(305 / 281 \mathrm{pm})$. Calculations of the bond valence sums $V_{i}=\sum_{j} \exp \left(\frac{R_{0}-d_{i j}}{b}\right)$ resulted in $V_{\mathrm{Eu} 1}=2.13$ and $V_{\mathrm{Eu} 2}=3.12\left(R_{0}=\right.$ $2.58 \AA, b=0.35 \AA)[22,23]$ and indicate the expected assignment of the europium valences. But in this case, the formula would be $\mathrm{Eu}_{2}^{2+} \mathrm{Eu}_{3}^{3+} \mathrm{Zr}_{3}^{4+} \mathrm{S}_{12}^{2-}$ and thus no longer charge neutral. This can be possible if the compound is metallic according to $\mathrm{Eu}_{2}^{2+} \mathrm{Eu}_{3}^{3+} \mathrm{Zr}_{3}^{4+} \mathrm{S}_{12}^{2-} \cdot 2 e^{-}$. However, the temperature dependent electrical resistance of $\mathrm{Eu}_{5} \mathrm{Zr}_{3} \mathrm{~S}_{12}$ shows semiconducting behavior (Figure 4). From the Arrhenius-plot we estimate a band-gap of $E_{\mathrm{G}} \approx 0.42 \mathrm{eV}$ at room temperature.

The static magnetic susceptibility $\chi_{\text {mol }}(T)$ and inverse susceptibility $\chi_{\mathrm{mol}^{-1}}{ }^{-1}(T)$ of $\mathrm{Eu}_{5} \mathrm{Zr}_{3} \mathrm{~S}_{12}$ is displayed in Figure 5. From the linear part of the $\chi_{\text {mol }}{ }^{-1}(T)$-plot between 7 and $300 \mathrm{~K}$ we extracted the effective magnetic moment $\mu_{\mathrm{eff}}=13.37(1) \mu_{\mathrm{B}} / \mathrm{fu}$ and the paramagnetic Curie temperature (Weiss-constant) $\theta=0.02(1) \mathrm{K}$. Thus, $\mathrm{Eu}_{5} \mathrm{Zr}_{3} \mathrm{~S}_{12}$ can be considered as Curie paramagnet. The experimental magnetic moment is close to the 
theoretical value of three $\mathrm{Eu}^{2+} / \mathrm{fu}\left(\sqrt{3} \times 7.94=13.75 \mu_{\mathrm{B}} / \mathrm{fu}\right)$. The magnetization behavior is presented in Figure 6 . At $40 \mathrm{~K}$, the magnetization increases linearly with increasing magnetic field as expected for a paramagnet. Magnetization measurements at $6 \mathrm{~K}$ show saturation, which perfectly fits to the Brillouin-function with three $\mathrm{Eu}^{2+}(J=$ $7 / 2$ ). No magnetic ordering is detected in agreement with $\theta$ close to zero.

The ${ }^{151} \mathrm{Eu}$ Mössbauer spectra of $\mathrm{Eu}_{5} \mathrm{Zr}_{3} \mathrm{~S}_{12}$ at 77 and $4.2 \mathrm{~K}$ are presented in Figure 7 together with transmission integral fits. The corresponding fitting parameters are listed in Table 4. In the whole temperature range, we observe two signals at isomer shifts around -12 and $0.5 \mathrm{~mm} / \mathrm{s}$, indicating static mixed valence of $\mathrm{Eu}^{2+}$ and $\mathrm{Eu}^{3+}$. There is no pronounced shift of the isomer shifts with decreasing temperature. At $4.2 \mathrm{~K}$ the area ratio of the two signals $\mathrm{Eu}^{2+} / \mathrm{Eu}^{3+}$ is 59/41, in good agreement with the ionic formula $\mathrm{Eu}_{3}^{2+} \mathrm{Eu}_{2}^{3+} \mathrm{Zr}_{3}^{4+} \mathrm{S}_{12}^{2-}$.

Thus, magnetic and Mössbauer spectroscopic data congruently show the existence of three divalent and two trivalent europium ions in $\mathrm{Eu}_{5} \mathrm{Zr}_{3} \mathrm{~S}_{12}$ in agreement with the semiconducting property. But this clearly contradicts with the crystal structure, because this would lead to implausible $\mathrm{Eu}-\mathrm{S}$ distances (vide supra). One may firstly think the crystal structure could be wrong. We were aware of possible twinning as found for some crystals of the similar orthorhombic thiostannate $\mathrm{Eu}_{5} \mathrm{Sn}_{3} \mathrm{~S}_{12}$, which simulated hexagonal symmetry. We checked for this and found no indication of twinning. The structure of $\mathrm{Eu}_{5} \mathrm{Zr}_{3} \mathrm{~S}_{12}$ was also smoothly refined by using x-ray powder data. Then we checked the behavior of the lattice parameters with temperature down to $10 \mathrm{~K}$ and found no anomaly. At the end, we have no indication of any inconstancy regarding the crystal structure of $\mathrm{Eu}_{5} \mathrm{Zr}_{3} \mathrm{~S}_{12}$.

To unravel this mystery, we suggest inhomogeneous mixed valence of the europium atoms at the $3 f$ site and pure divalent europium at the $2 c$ site in $\left(\mathrm{Eu}_{2}^{2+}\right)^{2 c}\left(\mathrm{Eu}^{2+} \mathrm{Eu}_{2}^{3+}\right)^{3 f} \mathrm{Zr}_{3}^{4+} \mathrm{S}_{12}^{2-}$. This would be consistent with the observed Eu-S distances, physical properties and Mössbauer spectroscopic data. A similar situation has been found in the low temperature phase of $\mathrm{Eu}_{3} \mathrm{~S}_{4}$ [7] with one pure $\mathrm{Eu}^{3+}$ site and one mixed site according to $\left(\mathrm{Eu}^{3+}\right)^{4 a}\left(\mathrm{Eu}^{2+} \mathrm{Eu}^{3+}\right)^{8 d} \mathrm{~S}_{4}^{2-}$ (space group $\left.I \overline{4} 2 d\right)$. 
As a chemical approach to this hypothesis, we tried to substitute the $\mathrm{Eu}^{2+}$ ions by $\mathrm{Sr}^{2+}$ ions with similar radius. We did not obtain phase pure samples, but small single crystals could be selected from the samples. The structure determination resulted in the composition $\mathrm{Eu}_{3.67} \mathrm{Sr}_{1.33} \mathrm{Zr}_{3} \mathrm{~S}_{12}$. Details of the crystal structure are given in Tables 1-3. The strontium atoms are distributed over both, the $2 c$ and the $3 f$ positions, but with a significant preference to the $2 c$ site providing the longer $\mathrm{Eu} / \mathrm{Sr}-\mathrm{S}$ distances in $\left(\mathrm{Eu}_{1.06} \mathrm{Sr}_{0.94}\right)^{2 c}\left(\mathrm{Eu}_{2.61} \mathrm{Sr}_{0.39}\right)^{3 f} \mathrm{Zr}_{3}^{4+} \mathrm{S}_{12}^{2-}$. This clearly supports the suggestion of inhomogeneous mixed valence at the $3 f$ site in $\mathrm{Eu}_{5} \mathrm{Zr}_{3} \mathrm{~S}_{12}$. However, this could be proved by Mössbauer spectroscopic experiments to high temperatures.

In summary, we have synthesized phase pure samples and single crystals of the mixed valence compound $\mathrm{Eu}_{5} \mathrm{Zr}_{3} \mathrm{~S}_{12}$. The crystal structure reported in [13] was confirmed, but the assignment of $\mathrm{Eu}^{2+}$ to the $3 f$-site with shorter $\mathrm{Eu}-\mathrm{S}$ distances and $\mathrm{Eu}^{3+}$ to the $2 c$ site with longer ones is very unlikely. Magnetic measurements and ${ }^{151} \mathrm{Eu}-$ Mössbauer spectra prove the existence of three $\mathrm{Eu}^{2+}$ and two $\mathrm{Eu}^{3+}$ in the unit cell. To solve these contradicting results, we suggest pure $\mathrm{Eu}^{2+}$ at the $2 c$ site and inhomogeneous mixed valence at the $3 f$ site according to $\left(\mathrm{Eu}_{2}^{2+}\right)^{2 c}\left(\mathrm{Eu}^{2+} \mathrm{Eu}_{2}^{3+}\right)^{3 f} \mathrm{Zr}_{3}^{4+} \mathrm{S}_{12}^{2-}$. This hypothesis is supported by the $\mathrm{Sr}^{2+}$ distribution in $\mathrm{Eu}_{3.67} \mathrm{Sr}_{1.33} \mathrm{Zr}_{3} \mathrm{~S}_{12}$. 


\section{References}

[1] C. M. Varma, Rev. Mod. Phys. 1976, 48, 219.

[2] E. R. Bauminger, D. Froindlich, I. Nowik, S. Ofer, I. Felner, I. Mayer, Phys. Rev. Lett. 1973, 30, 1053.

[3] R. Nagarajan, E. V. Sampathkumaran, L. C. Gupta, R. Vijayaraghavan, V. Prabhawalkar, Bhaktdarshan, B. D. Padalia, Phys. Lett. A 1981, 84A, 275.

[4] H. H. Wickman, E. Catalano, J. Appl. Phys. 1968, 39, 1248.

[5] F. Furuuchi, M. Wakeshima, Y. Hinatsu, J. Solid State Chem. 2004, 177, 3853.

[6] P. Jakubcova, D. Johrendt, C. P. Sebastian, S. Rayaprol, R. Pöttgen, Z. Naturforsch. 2007, 62b, 5 .

[7] H. Ohara, S. Sasaki, Y. Konoike, T. Toyoda, K. Yamawaki, M. Tanaka, Physica B: Condens. Matter 2004, 350, 353.

[8] G. Wortmann, E. V. Sampathkumaran, G. Kaindl, J. Magn. Magn. Mater. 1986, 54-57, 338.

[9] N. Lossau, H. Kierspel, J. Langen, W. Schlabitz, D. Wohlleben, A. Mewis, C. Sauer, Z. Phys. B: Condens. Matter 1989, 74, 227.

[10] G. Michels, C. Huhnt, W. Scharbrodt, W. Schlabitz, E. Holland-Moritz, M. M. Abd-Elmeguid, H. Micklitz, D. Johrendt, V. Keimes, A. Mewis, Z. Phys. B: Condens. Matter 1995, 98, 75.

[11] G. Michels, S. Junk, N. Lossau, W. Schlabitz, D. Wohlleben, D. Johrendt, A. Mewis, C. Sauer, T. Woike, Z. Phys. B: Condens. Matter 1992, 86, 53.

[12] V. Ksenofontov, H. C. Kandpal, J. Ensling, M. Waldeck, D. Johrendt, A. Mewis, P. Guetlich, C. Felser, Europhys. Lett. 2006, 74, 672.

[13]

[14] Y. L. I. Klawitter, Dissertation, Universität Kiel, 2004.

[15] EXPOSE, Stoe \& Cie GmbH, Darmstadt, 2000.

[16] X-RED32, 1.26 ed., Stoe \& Cie GmbH, Darmstadt, 2004.

[17] X-SHAPE, Stoe \& Cie GmbH, Darmstadt, 1999.

[18] G. M. Sheldrick, Acta Crystallogr. A 2008, A64, 112.

[19] KEITHLEY, Low Level Measurements, Precision DC Current, Voltage and Resistance Measurements, 5 ed., Keithley Instruments, Inc., Cleveland, Ohio, 1998.

[20] H. Lueken, Magnetochemie, Teubner, Stuttgart, Leipzig, 1999.

[21] S. Hatscher, H. Schilder, H. Lueken, W. Urland, Pure Appl. Chem. 2005, 77, 497.

[22] I. D. Brown, D. Altermatt, Acta Crystallogr. B 1985, B41, 244.

[23] N. E. Brese, M. O'Keeffe, Acta Crystallogr. B 1991, B47, 192. 
Table 1 Crystallographic data for $\mathrm{Eu}_{5} \mathrm{Zr}_{3} \mathrm{~S}_{12}$ and $\mathrm{Eu}_{3.67} \mathrm{Sr}_{1.33} \mathrm{Zr}_{3} \mathrm{~S}_{12}$

\begin{tabular}{|c|c|c|}
\hline Chemical formula & $\mathrm{Eu}_{5} \mathrm{Zr}_{3} \mathrm{~S}_{12}$ & $\mathrm{Eu}_{3.67} \mathrm{Sr}_{1.33} \mathrm{Zr}_{3} \mathrm{~S}_{12}$ \\
\hline Molar mass / g/mol & 1418.18 & 1332.61 \\
\hline Crystal system & hexagonal & hexagonal \\
\hline Space group & $P \overline{6} 2 m$ (Nr. 189) & $P \overline{6} 2 m$ (Nr. 189) \\
\hline \multirow[t]{2}{*}{ Lattice parameters /pm } & $\mathrm{a}=1170.7(2)$ & $\mathrm{a}=1167.0(2)$ \\
\hline & $c=394.27(8)$ & $c=395.71(8)$ \\
\hline $\mathrm{V} / 10^{6} \mathrm{pm}^{3}$ & $468(1)$ & $466.7(1)$ \\
\hline Formula units per cell & $Z=1$ & $Z=1$ \\
\hline Calculated density $/ \mathrm{g} / \mathrm{m}^{3}$ & 5.03 & 4.74 \\
\hline Absorption coefficient $/ \mathrm{mm}^{-1}$ & 19.4 & 18.8 \\
\hline Diffractometer & STOE IPDS & STOE IPDS \\
\hline Radiation type & $\operatorname{Mo} \mathrm{K}_{\alpha}(\lambda=71.073 \mathrm{pm})$ & $\operatorname{Mo} \mathrm{K}_{\alpha}(\lambda=71.073 \mathrm{pm})$ \\
\hline Data collection method & $\varphi$-scan, oscillation & $\varphi$-scan, oscillation \\
\hline Absorption correction & analytical & analytical \\
\hline Transm. Ratio (min/max) & $0.385 / 0.558$ & $0.354 / 0.567$ \\
\hline Total no. reflections & 5013 & 4130 \\
\hline Independent reflections & $566\left(R_{\text {int }}=0.0346\right)$ & $577\left(R_{\text {int }}=0.0747\right)$ \\
\hline Reflections with $I>2 \sigma(I)$ & 552 & 484 \\
\hline Parameter & 27 & 29 \\
\hline Goodness-of-fit $\left(F^{2}\right)$ & 1.259 & 0.968 \\
\hline \multirow[t]{2}{*}{ Final $R$ indices $(\mathrm{I}>2 \sigma(\mathrm{I}))$} & $R_{1}=0.0231$ & $R_{1}=0.0375$ \\
\hline & $w R_{2}=0.0631$ & $w R_{2}=0.0849$ \\
\hline \multirow[t]{2}{*}{$R$ Indices (all data) } & $R_{1}=0.0240$ & $R_{1}=0.0495$ \\
\hline & $w R_{2}=0.0636$ & $w R_{2}=0.0887$ \\
\hline Larg.diff peak and hole / e $\AA^{-3}$ & $3.13,-1.03$ & $3.00,-1.33$ \\
\hline Extinction coefficient & $0.0012(2)$ & $0.0013(5)$ \\
\hline
\end{tabular}


Table 2 Atomic coordinates and equivalent isotropic displacement parameters $\left(U_{\mathrm{eq}} / \mathrm{pm}^{2}\right)$ for $\mathrm{Eu}_{5} \mathrm{Zr}_{3} \mathrm{~S}_{12}$ and $\mathrm{Eu}_{3.67} \mathrm{Sr}_{1.33} \mathrm{Zr}_{3} \mathrm{~S}_{12}$ (space group: $P \overline{6} 2 \mathrm{~m}$ ).

\begin{tabular}{ccllllrl}
\hline $\mathbf{E u}_{\mathbf{5}} \mathbf{Z r}_{\mathbf{3}} \mathbf{S}_{\mathbf{1 2}}$ & Site & \multicolumn{1}{c}{$X$} & \multicolumn{1}{c}{$y$} & $z$ & $\underline{U}_{\mathrm{eq}}$ & occ. \\
\hline $\mathrm{Eu} 1$ & $2 c$ & $1 / 3$ & $2 / 3$ & 0 & $124(2)$ & \\
$\mathrm{Eu} 2$ & $3 f$ & $0.71674(5)$ & 0 & 0 & $104(2)$ & \\
$\mathrm{Zr}$ & $3 g$ & $0.3298(1)$ & 0 & $1 / 2$ & $128(3)$ & \\
$\mathrm{S} 1$ & $6 k$ & $0.2509(2)$ & $0.4424(2)$ & $1 / 2$ & $112(4)$ & \\
$\mathrm{S} 2$ & $3 f$ & $0.1783(3)$ & 0 & 0 & $171(6)$ & \\
$\mathrm{S} 3$ & $3 f$ & $0.4677(2)$ & 0 & 0 & $151(6)$ & \\
\hline $\mathbf{E u}_{\mathbf{3 . 6 7}} \mathbf{S r}_{\mathbf{1 . 3 3}} \mathbf{Z r}_{\mathbf{3}} \mathbf{S}_{\mathbf{1 2}}$ & & & & & & \\
\hline $\mathrm{Eu} 1$ & $2 c$ & $1 / 3$ & $2 / 3$ & 0 & $190(6)$ & 0.53 \\
$\mathrm{Sr} 1$ & $2 c$ & $1 / 3$ & $2 / 3$ & 0 & $190(6)$ & 0.47 \\
$\mathrm{Eu} 2$ & $3 f$ & $0.7184(1)$ & 0 & 0 & $161(3)$ & 0.87 \\
$\mathrm{Sr} 2$ & $3 f$ & $0.7184(1)$ & 0 & 0 & $161(3)$ & 0.13 \\
$\mathrm{Zr}$ & $3 g$ & $0.3297(2)$ & 0 & $1 / 2$ & $206(6)$ & \\
$\mathrm{S} 1$ & $6 k$ & $0.2506(4)$ & $0.4409(4)$ & $1 / 2$ & $177(8)$ & \\
$\mathrm{S} 2$ & $3 f$ & $0.1787(5)$ & 0 & 0 & $252(13)$ & \\
$\mathrm{S} 3$ & $3 f$ & $0.4674(5)$ & 0 & 0 & $252(13)$ & \\
\hline
\end{tabular}


Table 3 Selected bond lengths (in pm) for $\mathrm{Eu}_{5} \mathrm{Zr}_{3} \mathrm{~S}_{12}$ and $\mathrm{Eu}_{3.67} \mathrm{Sr}_{1.33} \mathrm{Zr}_{3} \mathrm{~S}_{12}$.

\begin{tabular}{|c|c|c|c|c|c|}
\hline \multicolumn{3}{|c|}{$\mathrm{Eu}_{5} \mathrm{Zr}_{3} \mathrm{~S}_{12}$} & \multicolumn{3}{|c|}{$\mathrm{Eu}_{3.67} \mathrm{Sr}_{1.33} \mathrm{Zr}_{3} \mathrm{~S}_{12}$} \\
\hline Eu1 & S1 & $303.0(2) 6 \times$ & Eu1/Sr1 & $\mathrm{S} 1$ & $304.0(3) 6 \times$ \\
\hline & S3 & $340.1(1) 3 \times$ & & S3 & $339.0(1) 3 \times$ \\
\hline & $\varnothing \mathbf{E u}-\mathbf{S}$ & 315.4 & & Ø Eu/Sr-S & 315.7 \\
\hline \multirow[t]{4}{*}{ Eu2 } & S1 & $286.5(2) 4 \times$ & Eu2/Sr2 & $\mathrm{S} 1$ & $285.9(2) 4 \times$ \\
\hline & S2 & 290.4(1) $2 \times$ & & S2 & $288.0(2) 2 \times$ \\
\hline & S3 & 291.5(3) & & S3 & $292.7(6)$ \\
\hline & $\varnothing \mathbf{E u}-\mathbf{S}$ & 288.3 & & $\varnothing \mathrm{Eu} / \mathrm{Sr}-\mathrm{S}$ & 287.5 \\
\hline \multirow[t]{4}{*}{$\mathbf{Z r}$} & S1 & $254.8(2) 2 \times$ & $\mathbf{Z r}$ & S1 & 253.9(4) $2 \times$ \\
\hline & S2 & 265.1(2) $2 \times$ & & S2 & 264.9(4) $2 \times$ \\
\hline & S3 & $254.9(2) 2 \times$ & & S3 & $255.0(4) 2 \times$ \\
\hline & $\varnothing \mathrm{Zr}-\mathrm{S}$ & 258.3 & & $\varnothing \mathrm{Zr}-\mathrm{S}$ & 257.9 \\
\hline
\end{tabular}

Table 4 Fitting parameters of ${ }^{151} \mathrm{Eu}$ Mössbauer spectroscopic measurements of $\mathrm{Eu}_{5} \mathrm{Zr}_{3} \mathrm{~S}_{12}$. Numbers in parentheses represent the statistical errors in the last digit. $(\delta)$, isomer shift; $(\Gamma)$, experimental line width; $\Delta \mathrm{E}_{\mathrm{Q}}$, electric quadrupole splitting parameter.

\begin{tabular}{llllllll}
\hline$T$ & $\delta_{1}$ & $\begin{array}{l}\Delta E_{Q 1} \\
\left(\mathrm{~mm} \mathrm{~s}^{-1}\right)\end{array}$ & $\begin{array}{l}\Gamma_{1} \\
\left(\mathrm{~mm} \mathrm{~s}^{-1}\right)\end{array}$ & $\begin{array}{l}\delta_{2} \\
\left(\mathrm{~mm} \mathrm{~s}^{-1}\right)\end{array}$ & $\begin{array}{l}\Delta E_{Q 2} \\
\left(\mathrm{~mm} \mathrm{~s}^{-1}\right)\end{array}$ & $\begin{array}{l}\Gamma_{2} \\
\left(\mathrm{~mm} \mathrm{~s}^{-1}\right)\end{array}$ & $A 1: A 2$ \\
\hline 77 & $-12.19(1)$ & $3.1(2)$ & $2.9(1)$ & $0.49(1)$ & $2.9(1)$ & $2.2(1)$ & $60: 40$ \\
4.2 & $-11.88(3)$ & $2.7(5)$ & $3.3(1)$ & $0.58(3)$ & $3.3(3)$ & $2.1(1)$ & $59: 41$ \\
\hline
\end{tabular}




\section{Figure Captions}

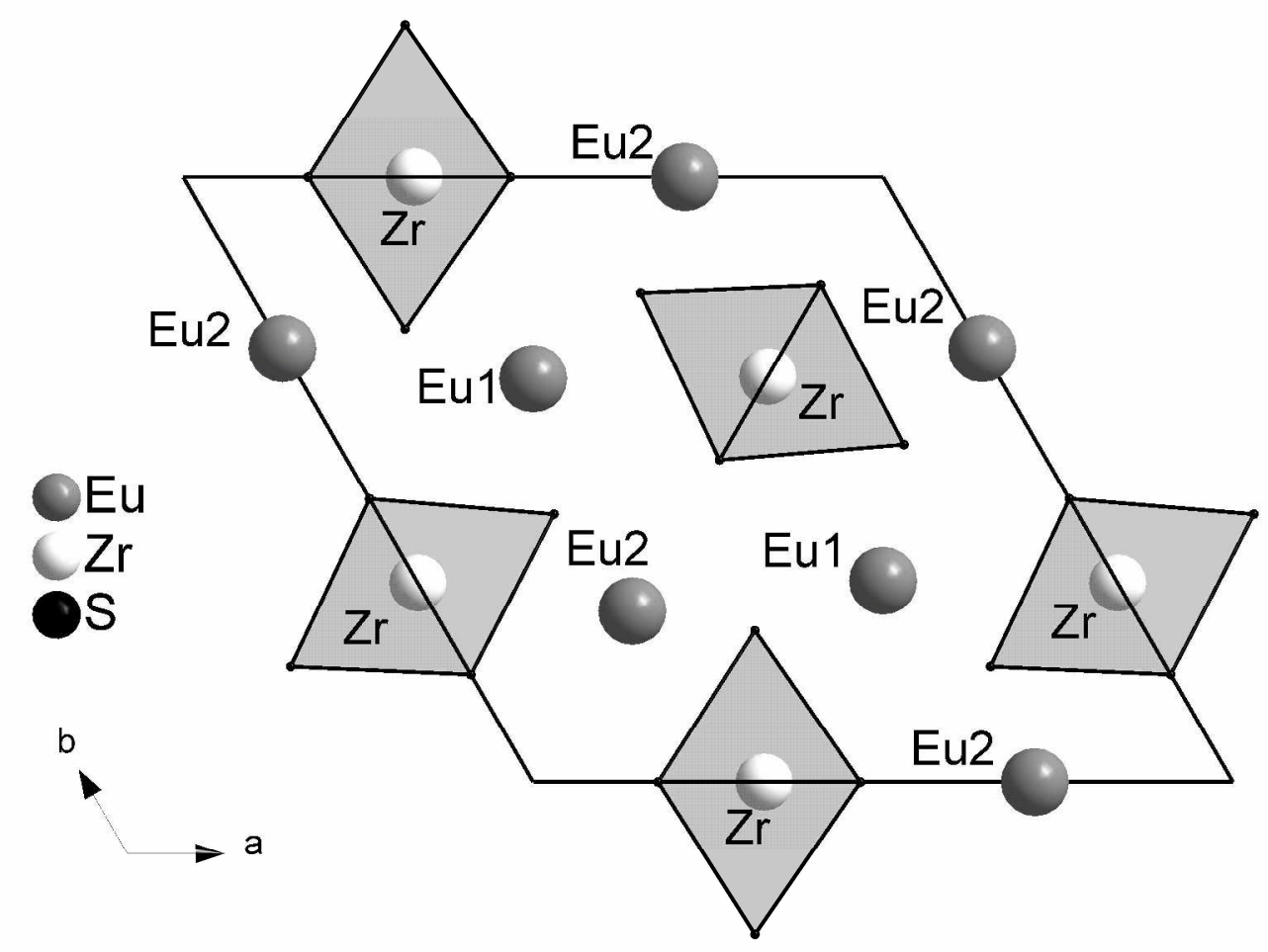

Figure 1. Crystal structure of $\mathrm{Eu}_{5} \mathrm{Zr}_{3} \mathrm{~S}_{12}$, projection onto the $a b$-plane. The octahedral zirconium coordination is emphasized.
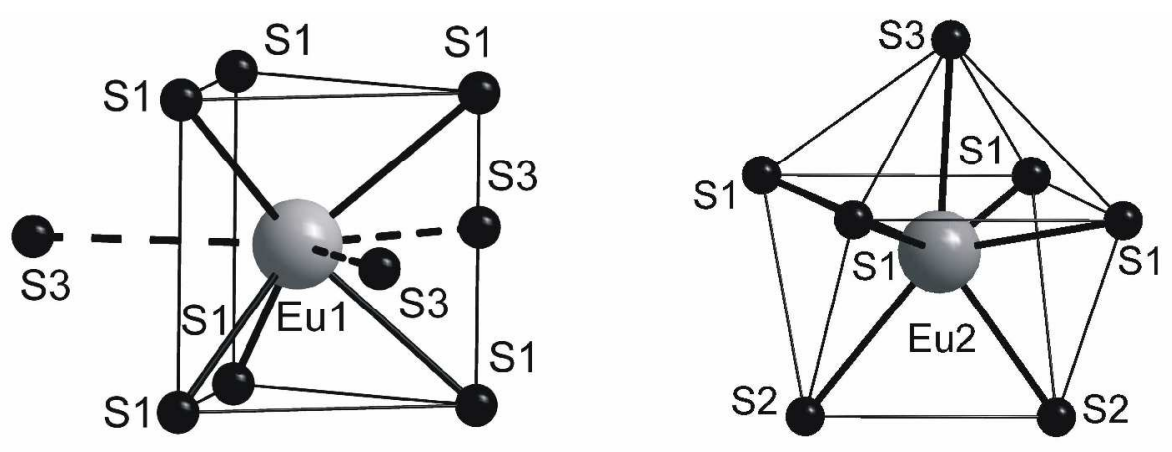

Figure 2. Coordination polyhedra of the $\mathrm{Eu}$ atoms in $\mathrm{Eu}_{5} \mathrm{Zr}_{3} \mathrm{~S}_{12}$. 


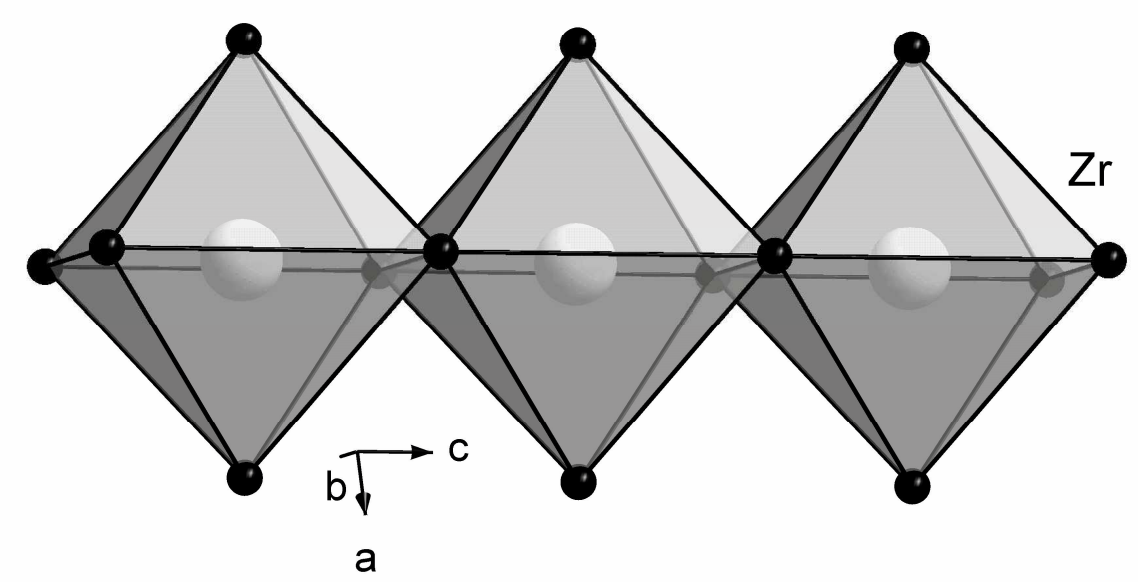

Figure 3. One-dimensional edge sharing octahedra in $\mathrm{Eu}_{5} \mathrm{Zr}_{3} \mathrm{~S}_{12}$.

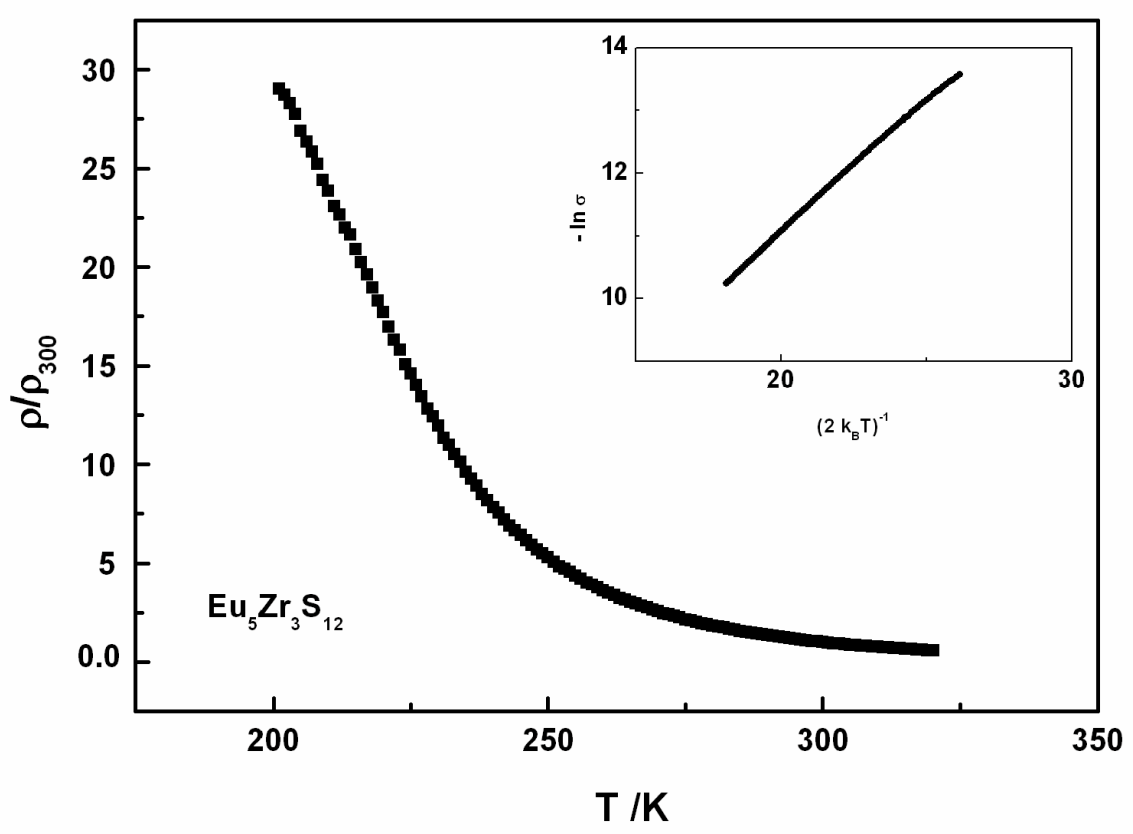

Figure 4. Temperature dependence of the relative resistivity of $\mathrm{Eu}_{5} \mathrm{Zr}_{3} \mathrm{~S}_{12}$. The inset shows the Arrhenius-plot. 


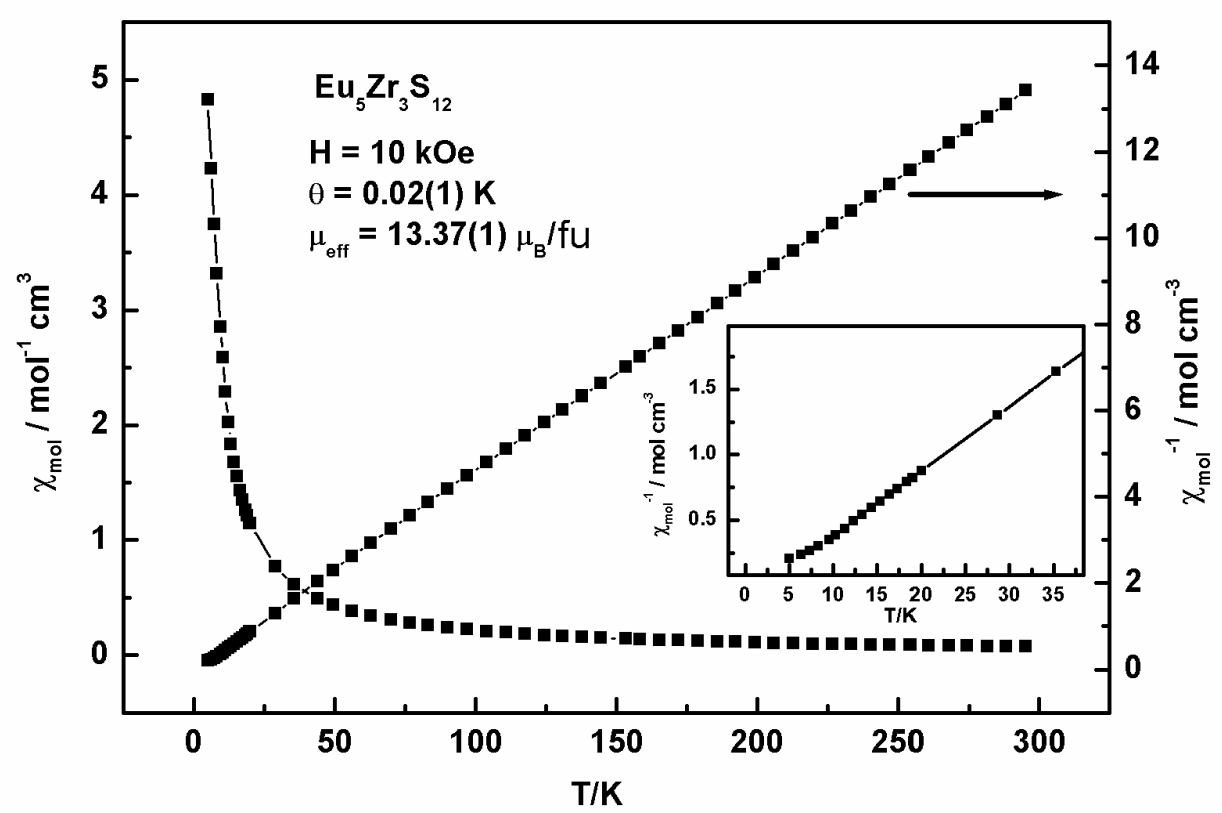

Figure 5. Temperature dependence of the magnetic susceptibility $(\chi)$ and inverse magnetic susceptibility $\left(\chi^{-1}\right)$ of $\mathrm{Eu}_{5} \mathrm{Zr}_{3} \mathrm{~S}_{12}$ measured in $\mathrm{H}=10 \mathrm{kOe}$. The behavior at low temperatures is shown in the insert.

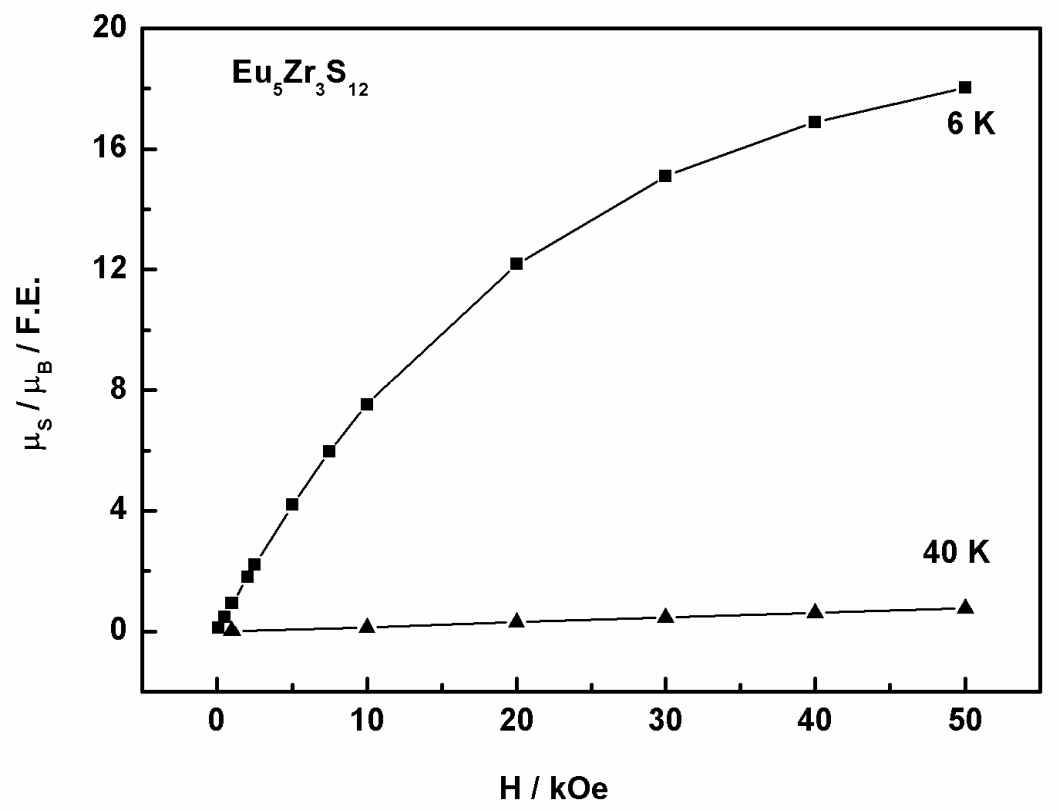

Figure 6. Magnetization as a function of ramping field measured at various temperatures for $\mathrm{Eu}_{5} \mathrm{Zr}_{3} \mathrm{~S}_{12}$. 


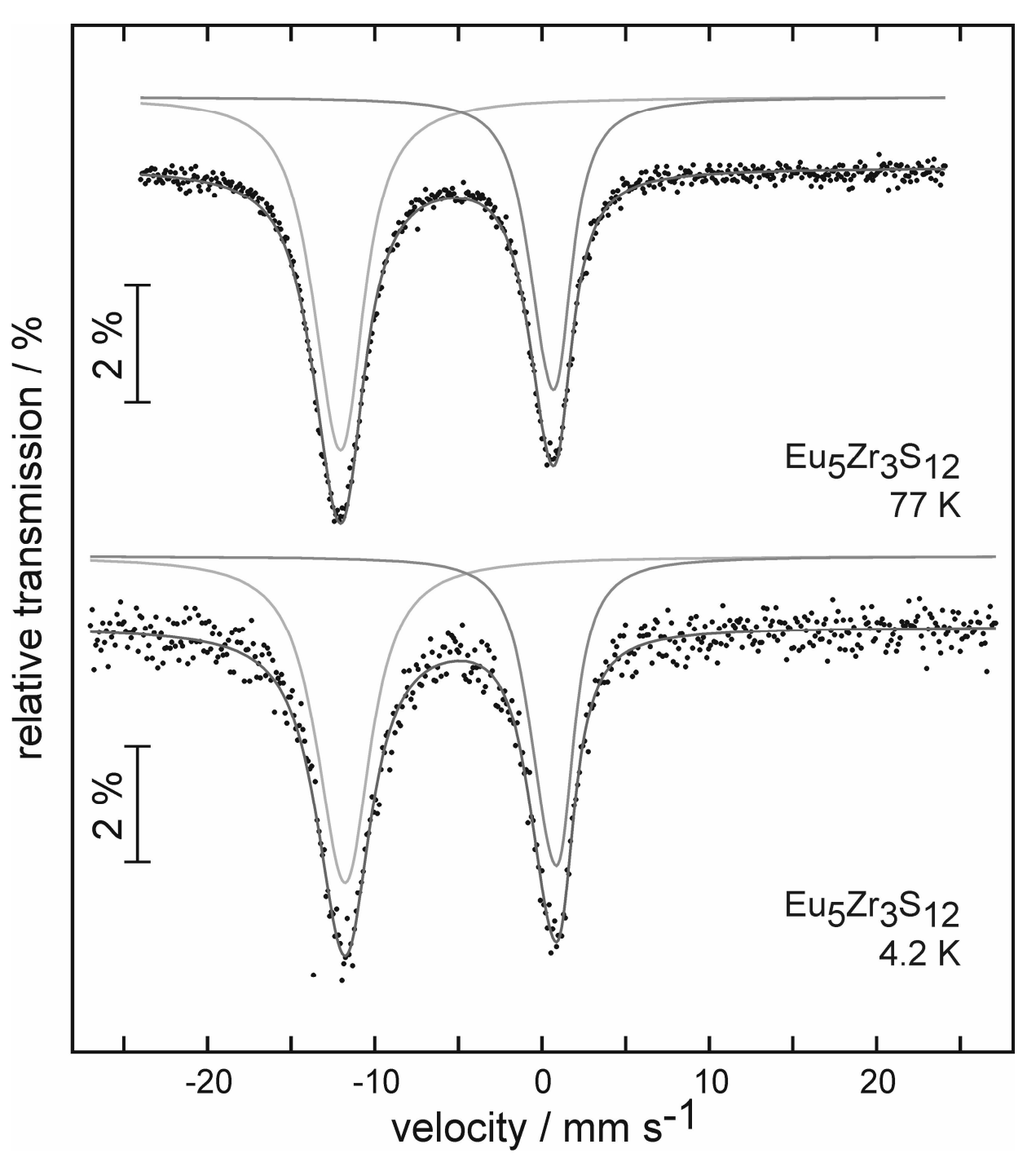

Figure 7. Experimental and simulated ${ }^{151} \mathrm{Eu}$ Mössbauer spectra of $\mathrm{Eu}_{5} \mathrm{Zr}_{3} \mathrm{~S}_{12}$ at 77 and $4.2 \mathrm{~K}$. 


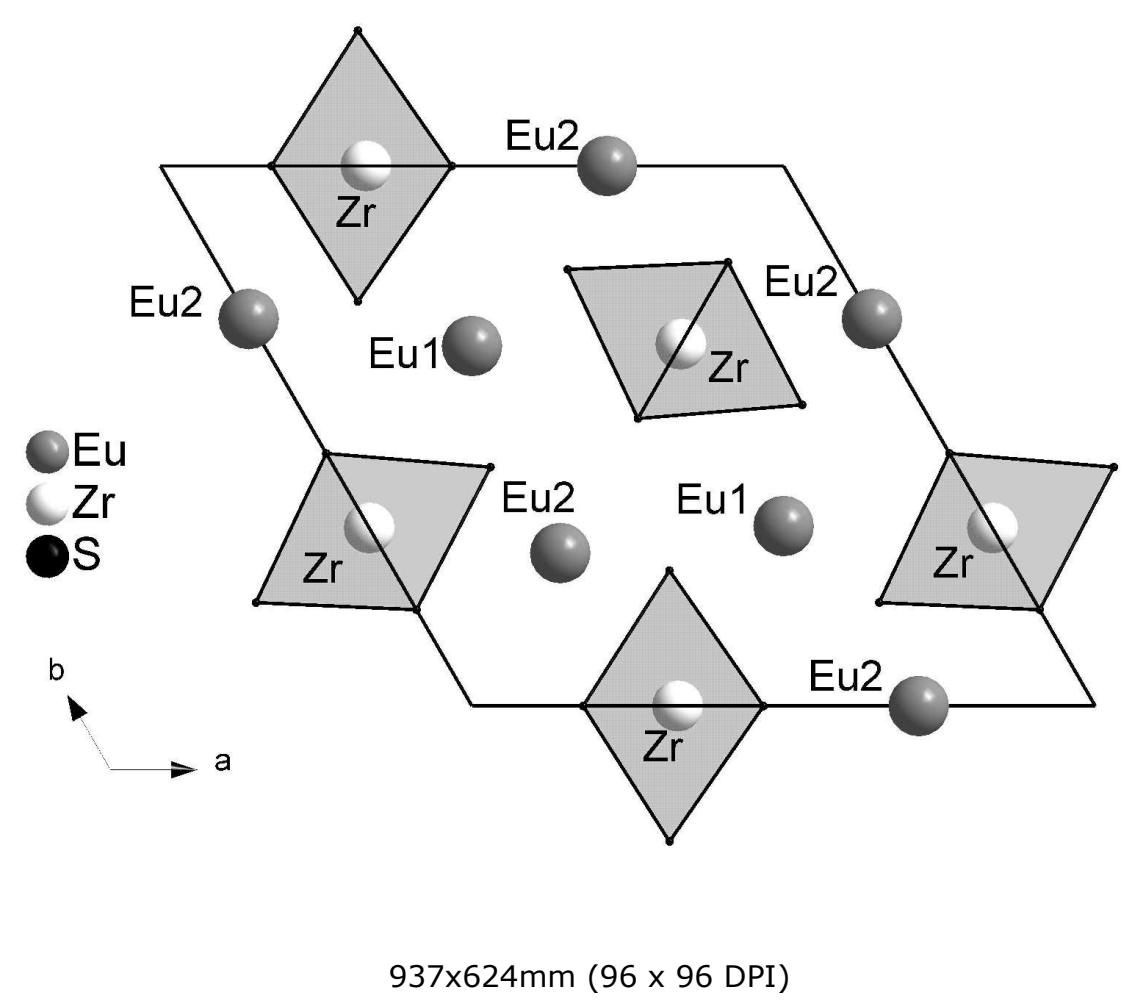

Wiley-VCH 

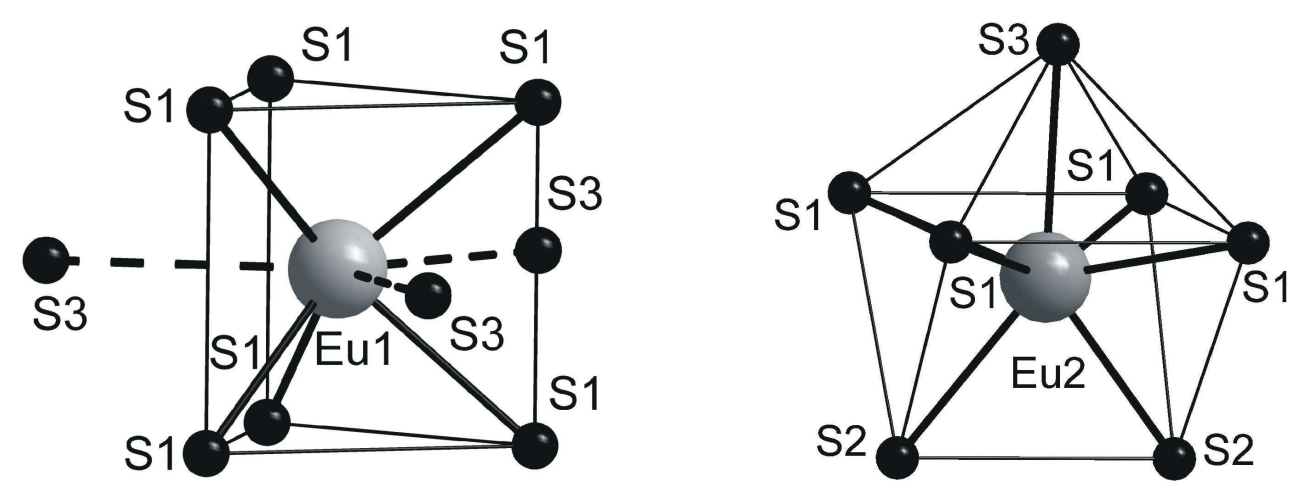

$119 \times 45 \mathrm{~mm}(600 \times 600$ DPI $)$ 


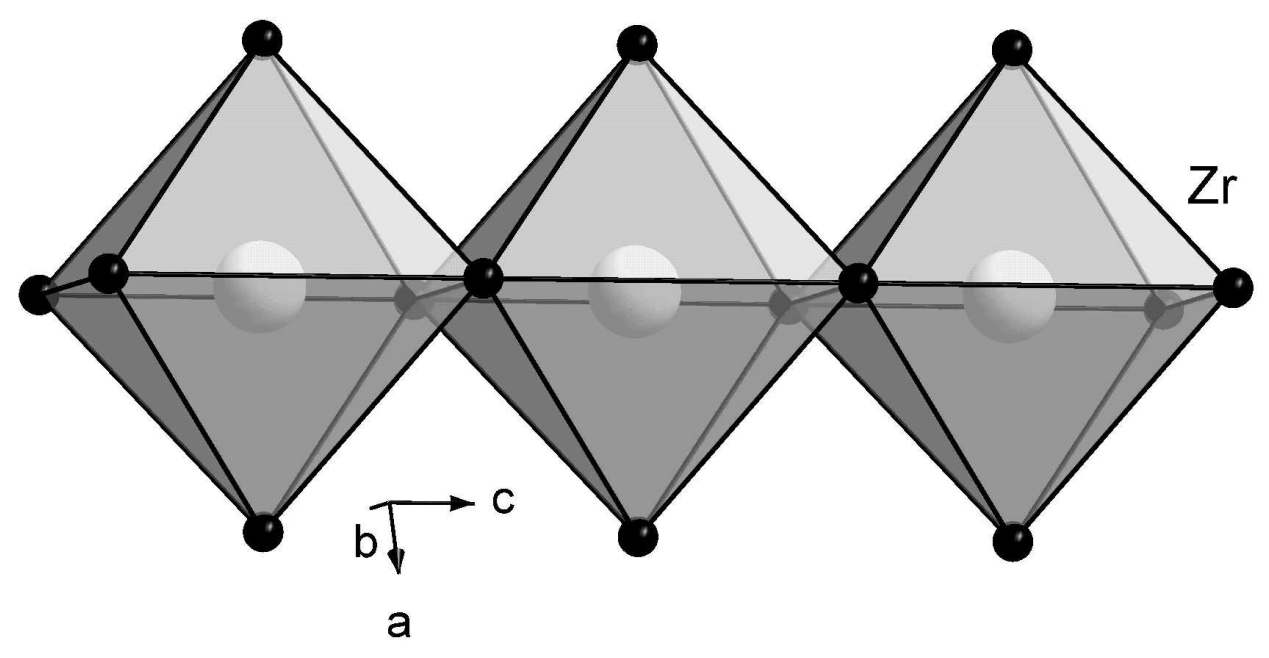

$937 \times 624 \mathrm{~mm}(96 \times 96 \mathrm{DPI})$

Wiley-VCH 


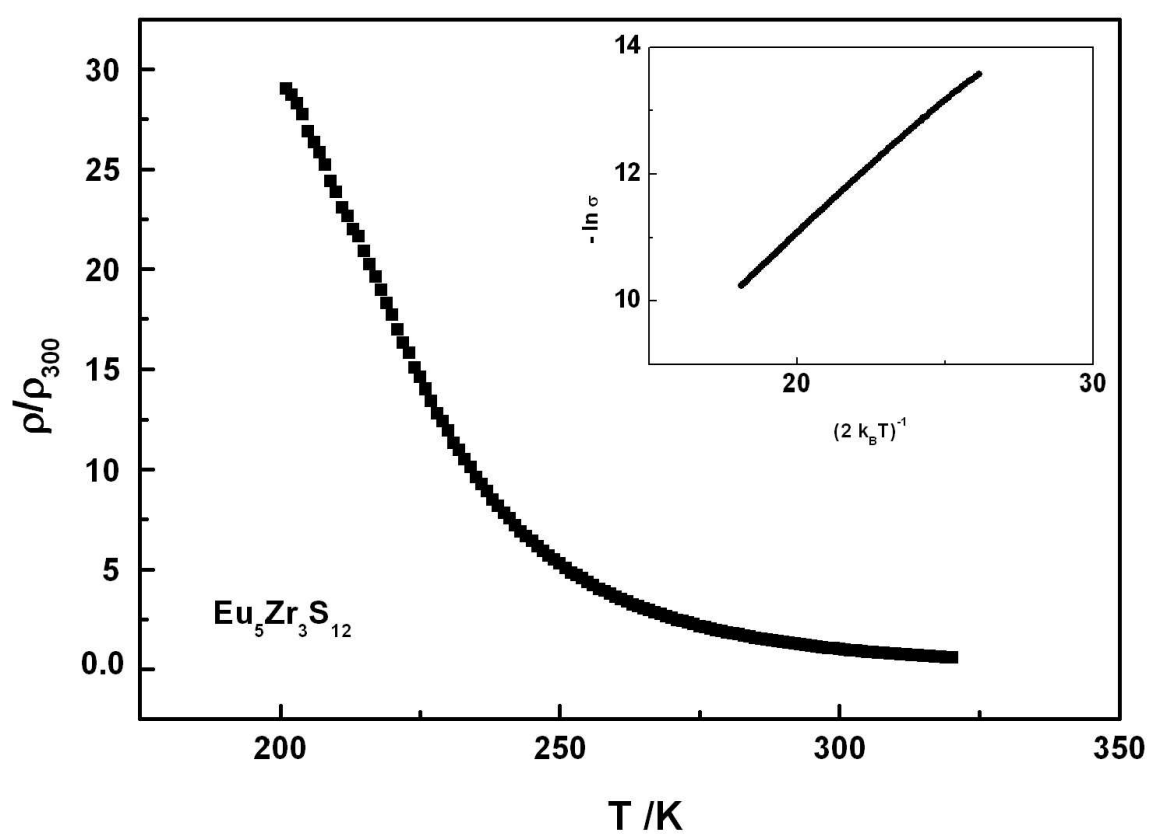

$283 \times 202 \mathrm{~mm}(150 \times 150 \mathrm{DPI})$ 


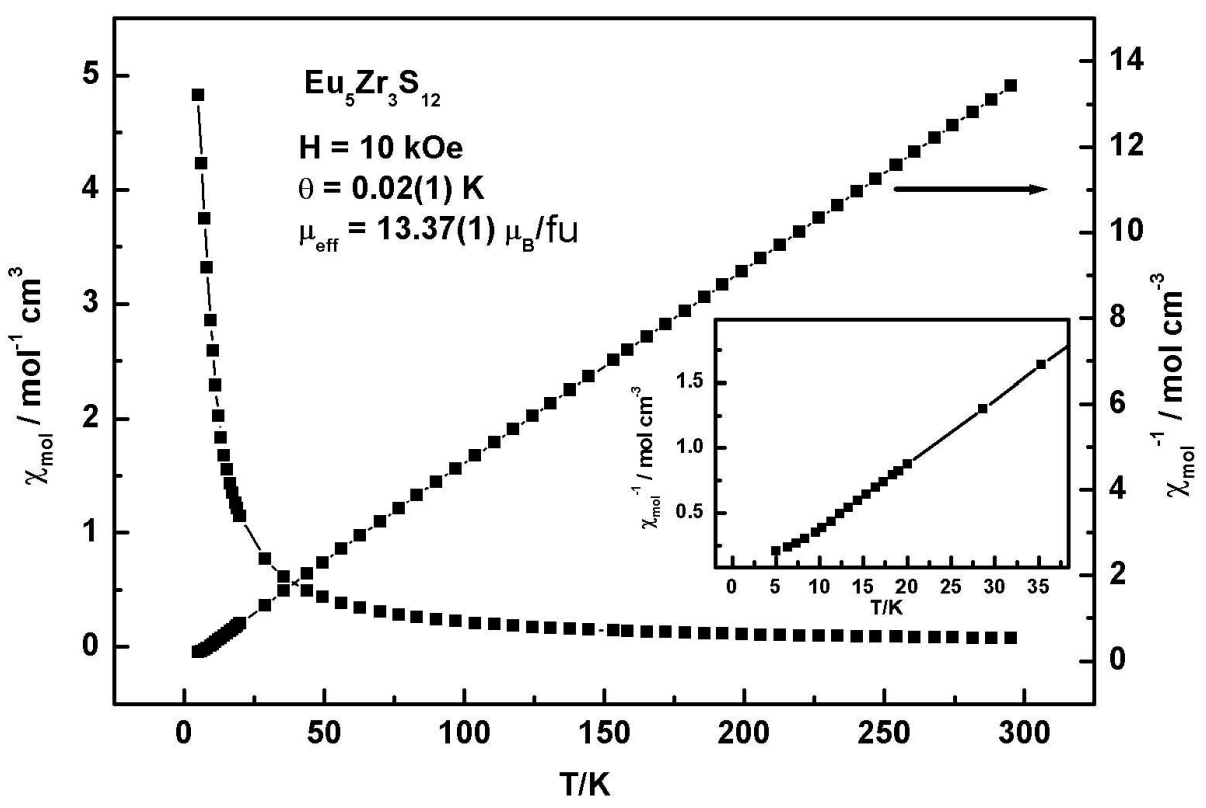

$284 \times 198 m m(150 \times 150$ DPI $)$ 


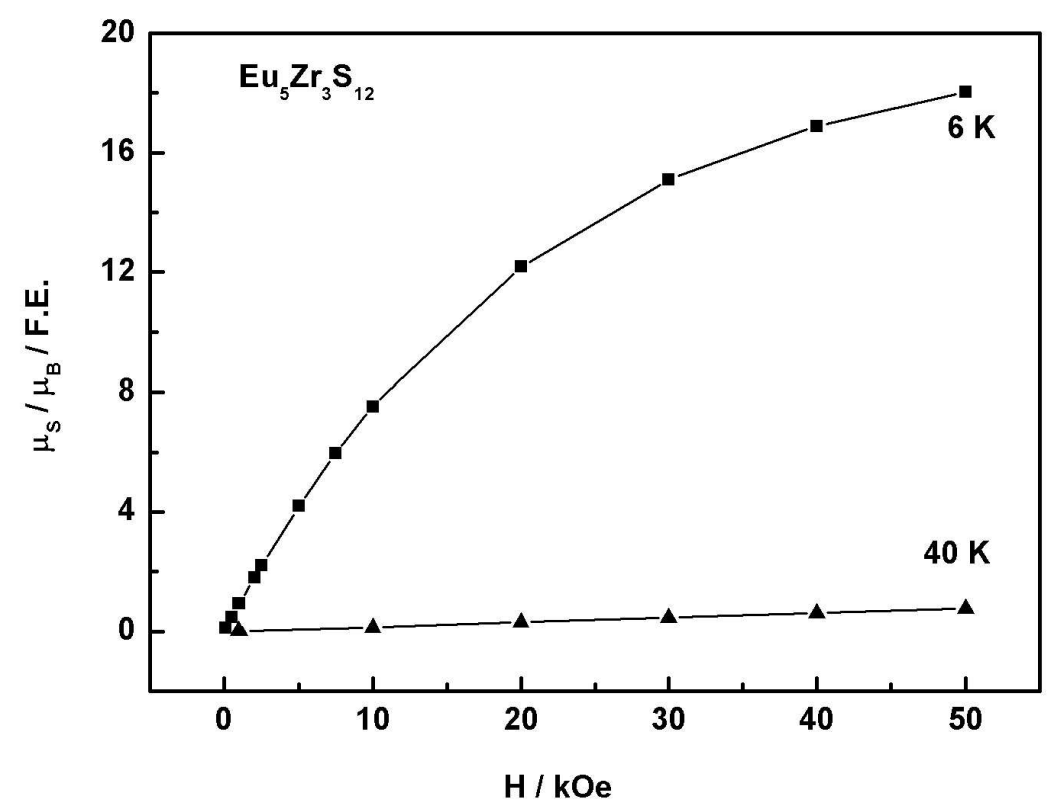

$288 \times 203 \mathrm{~mm}(150 \times 150 \mathrm{DPI})$ 


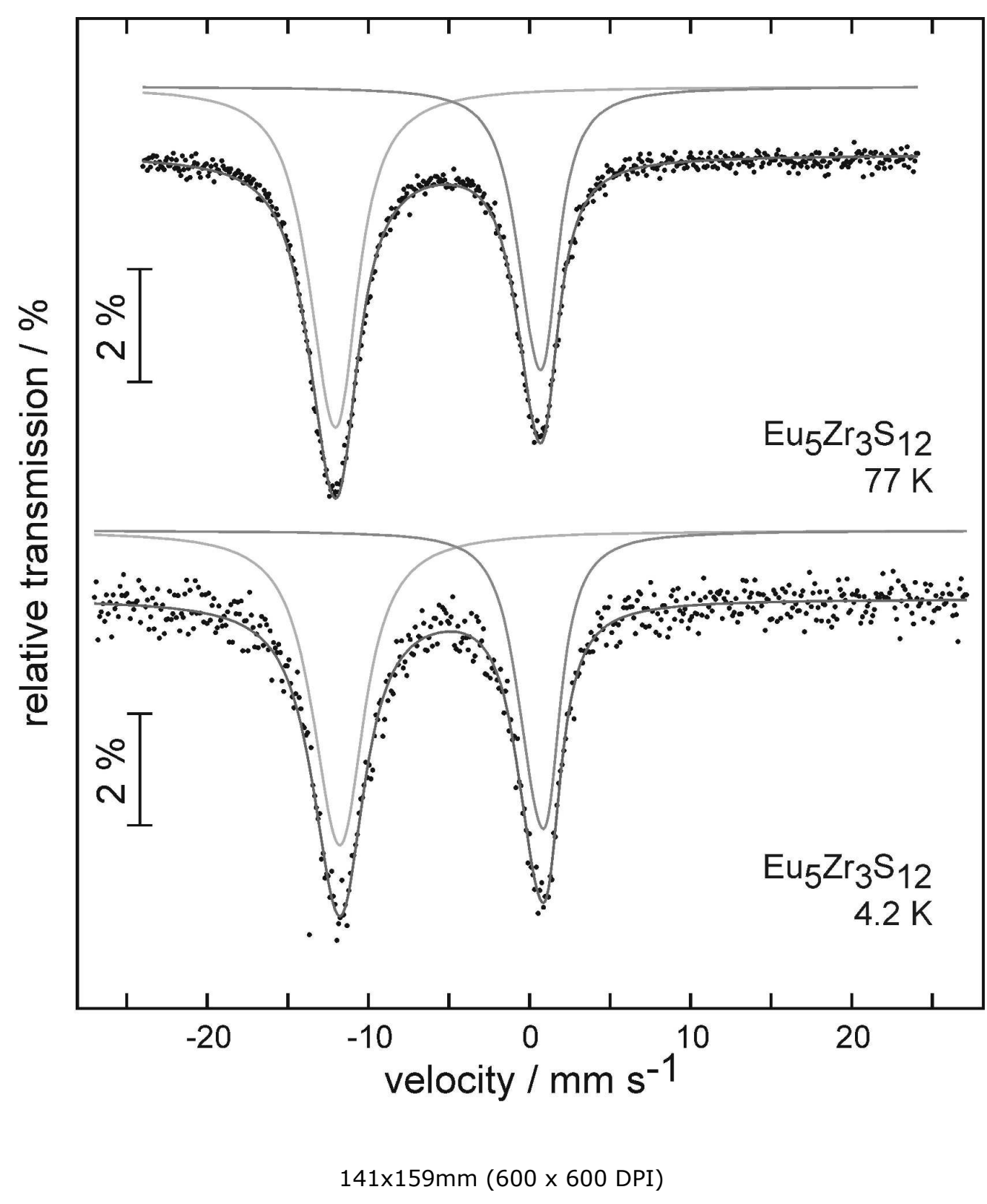

Wiley-VCH 